\title{
Research Progress on Aerobiology in the Last 30 Years: A Focus on Methodology and Occupational Health
}

\author{
Andrea Lancia ${ }^{1,2}$, Pasquale Capone ${ }^{1}$, Nicoletta Vonesch ${ }^{1}$, Armando Pelliccioni ${ }^{1}$, Carlo Grandi ${ }^{1}$, \\ Donatella Magri ${ }^{2}\left(\mathbb{D}\right.$ and Maria Concetta $\mathrm{D}^{\prime}$ Ovidio ${ }^{1, *}$
}

1 Department of Occupational and Environmental Medicine, Epidemiology and Hygiene, Italian Workers' Compensation Authority (INAIL), Monte Porzio Catone, 00078 Rome, Italy; andrea.lancia@uniroma1.it (A.L.); p.capone@inail.it (P.C.); n.vonesch@inail.it (N.V.); a.pelliccioni@inail.it (A.P.); ca.grandi@inail.it (C.G.)

2 Department of Environmental Biology, Sapienza University of Rome, Piazzale Aldo Moro 5, 00185 Rome, Italy; donatella.magri@uniroma1.it

* Correspondence: m.dovidio@inail.it

check for updates

Citation: Lancia, A.; Capone, P.; Vonesch, N.; Pelliccioni, A.; Grandi, C.; Magri, D.; D'Ovidio, M.C. Research Progress on Aerobiology in the Last 30 Years: A Focus on Methodology and Occupational Health. Sustainability 2021, 13, 4337. https://doi.org/10.3390/su13084337

Academic Editor:

Giouli Mihalakakou

Received: 8 March 2021

Accepted: 9 April 2021

Published: 13 April 2021

Publisher's Note: MDPI stays neutral with regard to jurisdictional claims in published maps and institutional affiliations.

Copyright: (c) 2021 by the authors. Licensee MDPI, Basel, Switzerland. This article is an open access article distributed under the terms and conditions of the Creative Commons Attribution (CC BY) license (https:// creativecommons.org/licenses/by/ $4.0 /)$.

\begin{abstract}
Aerobiology, as a scientific discipline, developed during the last century and has been applied to different types of organisms and scenarios. In the context of the Integrated Evaluation of Indoor Particulate Exposure (VIEPI) project, we conducted a bibliometric study of the scientific literature on aerobiology from the last three decades, establishing the recent advances and the critical issues regarding the application of aerobiological methods to occupational settings. The data were collected from Scopus, Web of Science and PubMed. We explored the distribution of the articles in different years and research areas and realized a bibliometric analysis using the CiteSpace software. The results indicated that the number of publications is increasing. The studies related to environmental sciences were the most represented, while the number of occupational studies was more limited. The most common keywords were related to pollen, fungal spores and their relation with phenology, climate change and human health. This article shows that aerobiology is not restricted to the study of pollen and spores, extending the discipline and the application of aerobiological methods to occupational settings, currently under-explored.
\end{abstract}

Keywords: aerobiology; systematic search; bibliometric analysis; databases; occupational health; methodology

\section{Introduction}

Aerobiology is the study of movement, passive transport, dispersion and deposition of material and particles of biological origin (endotoxins, mycotoxins, cells and spores of bacteria, fungal spores, aerosols, algal filaments, protozoan cysts, pollen), as well as airborne microorganisms, such as fungi, bacteria, viruses and mites, released in the atmosphere both outdoors and indoors, and potentially dangerous to animal, plants and human systems [1-6].

In this regard, it is fundamental to understand the interactions between biological particles and atmosphere and how physical factors (weather and climate) affect aerosol particles' release, movement, deposition and impact on vegetation and different substrates $[3,5,7,8]$. The fields of application of aerobiology are numerous and heterogeneous and concern medicine (both human and animal diseases, immunology, occupational hygiene), agriculture (plant pathology, pest management, arthropod dispersal), forestry and gene ecology, meteorology, climatology, biometeorology, microbiology, biodeterioration, indoor and outdoor air quality, air pollution, industrial aerobiology, palaeobotany and so on $[2,9]$.

One of the main motivations for the development of aerobiology as a scientific discipline has been the necessity of understanding the diffusion of human, animal and plant diseases in order to prevent them. Hence, the outdoor spread of pollen and fungal spores 
has been the main field of application, while the ecology of the air itself has been of secondary interest [5]. Aerobiology was a topic in the Integrated Evaluation of Indoor Particulate Exposure (VIEPI) project, aimed at evaluating indoor air quality and workers' exposure to particulate matter (PM) [10]. Chemical and biological characterization of PM was performed and exposure to pollen and fungal spores sampled in indoor and outdoor workplaces was studied in order to improve preventive and protective measures for occupational health.

The aims of this study were: (1) to analyze the number and type of scientific articles regarding aerobiology published in the last 30 years; (2) to identify the changes of interest trends over the years in different research areas and for related keywords; (3) to underline the interconnection between aerobiology, occupational health and climate change; (4) to provide tips on innovative methodologies to improve exposure assessment and health surveillance practices.

\subsection{Historical Background}

The origin of aerobiology can be traced back in time, especially when considering its relationship with human health. The perception that particles transported by the air (or the air itself) could cause harm to humans, leading to outbreaks such as pestilences, has always been part of human cultures, particularly in Western societies. Traces of this awareness can be found in the works of ancient authors like Lucretius or Hippocrates. At the dawn of the modern era, with the advancement of science and the development of new technologies, studying biological particles in the air became more than just a theoretical idea, as shown by the observations of Anton van Leeuwenhoek, who described small "animalcules" floating in the air and observed them through his lenses in 1680 [11], or in the experiments on mold spores conducted by the Italian botanist Pier Antonio Micheli [12]. Scientists like J.G. Koelrueter, C.P. Sprengel and T.A. Knight continued to perform observations on airborne particles in the 18th century [4]. The importance of airborne biological particles in the life cycle of several organisms and their impact on human health was established by the experiments on spontaneous generation, including the ones performed by Lazzaro Spallanzani in the late 18th century and by Louis Pasteur in the 19th century [13]. Following the findings of Pasteur, many researchers around the world approached the study of biological particles in the air. In the 1870s John Tyndall discovered the presence of bacterial endospores on the surface of hay fragments with the ability to transmit fevers [13]. The rising interest towards this subject led to the development of sampling systems and devices to study the particle content of the air. In 1870 Richard Leach Maddox invented an instrument to collect bioaerosol particles he called an "aeroconiscope" [14]. Later, a similar method was used by David Douglas Cunningham, who was studying cholera in Calcutta in the same period [15]. The aeroconiscope he used consisted in a funnel that directed the air on a microscope slide covered with adhesive material. Using this instrument, Cunningham caught mainly fungal spores and pollen. A similar method, based on an active pump to maintain a regular and adjustable airflow, was used by Pierre Miquel in the Observatoire Montsouris (opened in France in 1871) to perform a quantitative estimation of spores [16]. The first real monitoring of pollen and fungal spores for medical purposes was realized in the UK by Blackley in 1870 [17]. Walther Hesse and Percy Faraday Frankland performed several studies on aerobiological particles in the late 19th century [18-21], mainly focused on bacteria and spores, sampled by passive deposition on Petri dishes. Between the end of the 19th century and the early 1910s, only a few works on aerobiology were published and few improvements in the sampling methods were made, with the passive gravity deposition on slides being the most prominent [22]. In 1912, Hans Molisch used the term "aeroplankton" to describe the ensemble of biological particles passively transported through the atmosphere [23].

The birth of a new discipline was ultimately established with the invention of the term "aerobiology", used for the first time by Fred Campbell Meier in the 1930s, but he died before his work was published [24]. He used a peculiar sampling instrument, called a 
"sky-hook", placed on planes to collect suspended particles during their flight [23]. Meier's terminology was adopted by other researchers and discussed during a symposium on extramural and intramural aerobiology organized by the American Association for the Advancement of Science [25]. In 1943, the first continuous pollen sampling was performed in Cardiff [26-28]. One of the founders of the discipline was Philip Herries Gregory, who invented the term "air spora" to designate the microscopic particles released in the atmosphere by living beings [29]. Gregory played a pivotal role in spreading the interest in aerobiology [30,31], undertaking important studies on the dispersion of airborne spores [32] focused on the physical mechanics of spore and pollen dispersal in the atmosphere [4]. An important advancement in aerobiology was the invention of an automatic volumetric spore trap by Jim Hirst in 1952 [33]. This machine could operate automatically for several days, actively pumping air and collecting particles on a sampling strip covered with silica gel and placed on a clockwork cylindrical drum. Hirst-type samplers have become a staple for aerobiological sampling and are still widely used. An alternative sampling system based on rotating arms covered with sticky material was developed by Perkins in 1957, called a "rotorod sampler" [34]. The rotorod sampler is still a relevant sampling method, mainly used in the USA, while in most of other countries Hirst-type or other samplers (e.g., the Durham sampler or automatic samplers, mainly the KH-3000 in Japan) are preferred for continuous outdoor monitoring [35]. The widespread application of these sampling methods led over time to the development of several stable aerobiological monitoring stations, often linked to regional or national networks. These aerobiological networks, focused on the study of pollen and fungal spores in the outdoor air, can contribute to the safeguarding of the general population's health by publishing on a daily basis quantitative data on pollen and spores.

The global community of the researchers dealing with aerobiology began to organize in 1964, with the establishment of the International Biological Program (IBP) and the constitution of the International Aerobiology Working Group in 1968, with the aim of coordinating the various national aerobiological groups. The International Association of Aerobiology (IAA; https: / /iaaerobiology.wordpress.com/, accessed on 10 November 2020) was established in 1972.

Recently, new techniques for aerobiological monitoring have been developed, including molecular techniques [36-38] and analyses based on immunochemical assays, like the enzyme-linked immunosorbent assay (ELISA) [39,40] and immunofluorescence assay (IFA), which recognize allergens on airborne particles through fluorescence. Some of these techniques have also been used to develop real-time sensing methods, which operate through continuous and automatized sampling followed by automated aerosol particle recognition through different methods, such as fluorescence spectroscopy [41-46], mass spectrometry, microscopy and others [47]. Real-time techniques represent a new frontier for aerobiology but are still under development and require accurate interpretation of the processed data [47]. Nowadays, as previously cited [35], traditional quantitative methods such as Hirst-type and rotorod samplers are still widely used for pollen and fungal spores monitoring, while methods for sampling microorganisms are based on the collection of culturable particles [48], like passive traps, cascade impactors [49], liquid impingers [50], centrifugal and cyclone samplers [51], filters [52] and electrostatic precipitators [53,54].

\subsection{Aerobiology and Occupational Health}

In the last decades, different categories of indoor and outdoor workers have been identified as exposed to biological risk due to airborne particles and microorganisms [55].

Monitoring aerobiological particles (especially pollen and fungal spores) responsible for allergies and other disorders (asthma, rhinitis, and hypersensitivity pneumonitis) can be viewed as a valid support in occupational medicine [56]. In fact, the presence of different environmental sources of airborne particles in workplaces, affected by pollution and meteorological variables, jointly with individual susceptibility factors (collectively leading to hypersensitivity) may have caused the increase of occupational allergies with 
clinical symptoms, ranging from discomfort to adverse severe reactions [57]. The agricultural sector is regarded as being at risk for occupational allergy and respiratory diseases $[55,56,58,59]$. Farmers and zootechnical workers could be exposed to dust containing bacteria, secondary metabolites (e.g., mycotoxins), components of fungal cell walls (e.g., $(1 \rightarrow 3)$ - $\beta$-D-glucan) and spores from fungi growing on plants, grains and pollen or derived from animals [56,59-63]. Workers employed in activities such as waste and compost handling, grain and animal feed handling, mills, the food industry, wood processing and handling, metalworking, detergent enzyme manufacturing, seafood processing and fisheries sectors could also be exposed to biological risk due to inhalation of dust rich in bacteria, molds and endotoxins, all potentially affecting respiratory functions $[55,58,63-68]$. Moreover, categories such as veterinarians and laboratory workers, who handle laboratory animals, could be exposed to hazardous microorganisms and allergenic agents [55].

Aerobiological monitoring can be considered a valid tool in the control of indoor air quality, since workers and people spend most of their time in indoor environments (offices, schools, shopping centers, restaurants, etc.) [57,69]. Workers in offices and buildings with many occupants may be exposed to various airborne particles (viruses, bacteria, pollen and fungal spores) due to human presence and actions (opening/closing doors or windows, switching the air conditioning on and off) [1,70]. Hazardous aerobiological agents could affect workers' health in other indoor environments (archives, libraries and heritage storage rooms) [71]. Lastly, workers employed in several indoor settings (e.g., hotels, cruise ships, aircraft cabins) may be exposed to bacteria and viruses spread via airborne/droplets and/or aerosols (e.g., Mycobacterium tuberculosis, Neisseria meningitidis, influenza virus, measles virus, SARS-CoV-2), in addition to other biological agents, such as molds and allergens, through ventilation system or open windows/doors [1,55,72]. In this context, a multidisciplinary approach also focused on vulnerable workers (e.g., pregnant women, elderly workers, immunocompromised subjects) may be effective for the development and implementation of preventive measures for occupational health safety [55].

\section{Materials and Methods}

\subsection{Data Collection: Systematic Search}

The selected databases to conduct the search were Scopus, Web of Science (WoS) and PubMed. In all three databases, the search was performed by looking for the inserted terms in the title, abstract and keywords of papers. To achieve this, we used the TITLE-ABS-KEY search in Scopus, the Topic search in WoS, and the [Title/Abstract] search in PubMed. In WoS, the data were collected from the Web of Science Core Collection. The initial searches were conducted without applying any time limitation in order to obtain a comprehensive overview of the publishing history in aerobiology. For each search, the total number of papers and the number of papers per year were recorded. All data were collected up to June 2020. The main search item used was the word aerobiology, which was firstly searched by itself, then paired, using the AND Boolean operator, with other keywords (or several keywords coupled through OR), such as weather, meteorology, environmental, pollution, occupational, outdoor, indoor, pollen, fungi, "fungal spores", animal, bacteria or virus, methodology, climate and "climate change". In Scopus and WoS the option "Analyze results" was also used to evaluate the distribution of the papers in different disciplinary research areas and their document type. The results were arranged by year of publication in order to evaluate the change in the number of published papers over the years, considering every year of publication. Then, to analyze the changes in the most used research areas, we focused on the publications in the years 1990-2019, grouping them into ten-year intervals, obtaining three decades: 1990-1999, 2000-2009, 2010-2019. In WoS, only the "Web of Science Category" classification was considered.

\subsection{Data Analysis}

The analysis on the bibliographic data was conducted using CiteSpace (version 5.7 R2) (http:/ / cluster.cis.drexel.edu/ cchen/ citespace/, accessed on 10 November 2020), a widely 
utilized java-based software for bibliometric analysis [73]. CiteSpace operates by analyzing co-citation networks [74] and building graphical visualizations of those networks. Cocitation means that two elements (e.g., single words, documents, authors) are both present in a single paper. The networks can be built based on different criteria, such as co-authors, co-citation references, co-occurring keywords and subject areas [75]. The obtained networks are composed of two parts: nodes and links. The nodes have a radius which is directly proportional to the number of times that a specific element is found in the analyzed data; the links connect two different nodes, and their width is proportional to the times the two elements are found in association. CiteSpace can categorize the nodes of a network in different clusters, and can also be used for other types of analysis, like burst detection, a feature indicating a sharp increase of interest in a certain subject or a keyword in a short period of time. CiteSpace calculates burstness based on the Kleinberg algorithm [76].

The database used for the analysis was obtained from Web of Science, exporting the research results as "Full Record" text files. CiteSpace was used to create networks based on different criteria: subject areas, keywords, countries. For the subject areas, only the "Web of Science Categories" were used for the analysis, excluding the "Subject Categories". The same software was utilized to investigate bursts. The parameters in CiteSpace were set as follows: Time slicing from 1990 to 2019, years per slice $=1$; Node type $=$ country, institution, keyword, category; Look back years $=-1$ (infinite); Pruning $=$ Pathfinder, pruning of the merged network; Select top 50 levels of most cited or occurred items for each slice; for the "keyword" node type analysis, the "keyword plus" option was not selected, and only the keywords used by the authors were used; all the other settings were left as default. A cluster analysis was also performed on the networks to find the most relevant groups of nodes. Burstness analysis was performed by leaving all parameters as default.

\section{Results and Discussion}

\subsection{Article Numbers, General Data and Trends}

The total number of articles (last accessed 18 June 2020) for the basic aerobiology keyword search (Table 1) was 1257 in Scopus, 898 in WoS and 295 in PubMed. The most relevant outputs of compound searches were aerobiology AND pollen (Scopus: 825; WoS: 521; PubMed: 136), aerobiology AND environmental (Scopus: 416; WoS: 139; PubMed: 52), aerobiology AND climate (Scopus: 208; WoS: 152; PubMed: 33), aerobiology AND (bacteria OR virus) (Scopus: 236; WoS: 101; PubMed: 33).

Table 1. Total number of papers obtained for each search input in the three different databases up to 18 June 2020. These results consider every year of publication, from the date of the first published article (1938) to 18 June 2020.

\begin{tabular}{lccc}
\hline Search Input & Scopus & WoS & PubMed \\
\hline aerobiology & 1257 & 898 & 295 \\
aerobiology AND pollen & 825 & 521 & 136 \\
aerobiology AND environmental & 416 & 139 & 52 \\
aerobiology AND fungi & 321 & 116 & 23 \\
aerobiology AND climate & 208 & 152 & 33 \\
aerobiology AND (bacteria OR virus) & 236 & 101 & 33 \\
aerobiology AND weather & 188 & 123 & 35 \\
aerobiology AND pollution & 208 & 78 & 12 \\
aerobiology AND “fungal spores” & 158 & 114 & 10 \\
aerobiology AND indoor & 113 & 66 & 21 \\
aerobiology AND “climate change” & 82 & 91 & 17 \\
aerobiology AND outdoor & 87 & 58 & 18 \\
aerobiology AND meteorology & 123 & 32 & 7 \\
aerobiology AND methodology & 90 & 54 & 13 \\
aerobiology AND animal & 77 & 29 & 7 \\
aerobiology AND occupational & 29 & 18 & \\
\hline
\end{tabular}


The most common type of document (Figure 1) was the article, accounting for over $80 \%$ of the total number of documents in Scopus and WoS, with other types of papers, such as reviews and proceedings/conference papers, contributing less than $7 \%$ each.

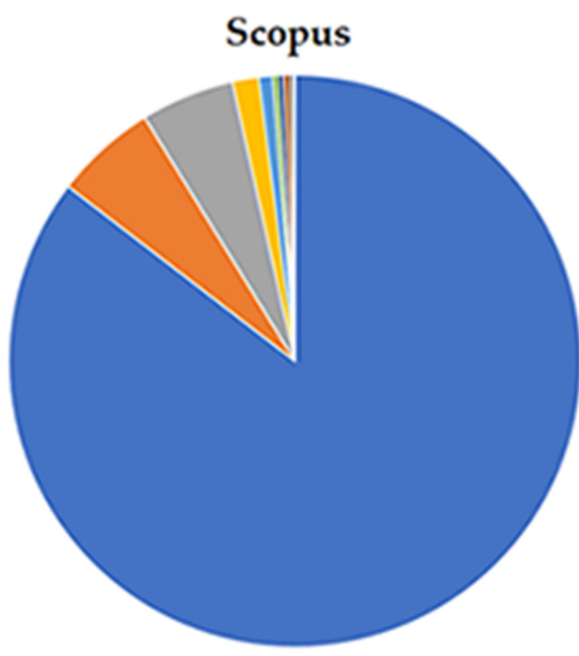

(a)

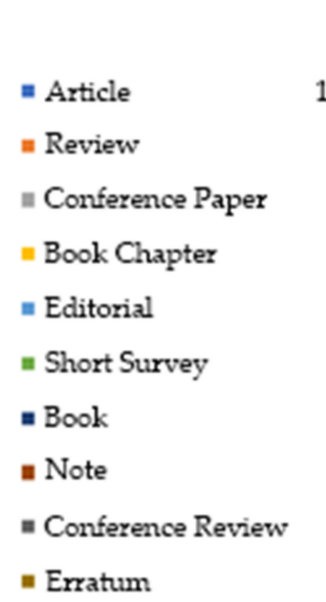

$\begin{array}{cc}\mathrm{N} & \% \\ 1098 & 85.45 \\ 74 & 5.76 \\ 68 & 5.29 \\ 19 & 1.48 \\ 10 & 0.78 \\ 4 & 0.31 \\ 4 & 0.31 \\ 4 & 0.31 \\ 3 & 0.23 \\ 1 & 0.08\end{array}$

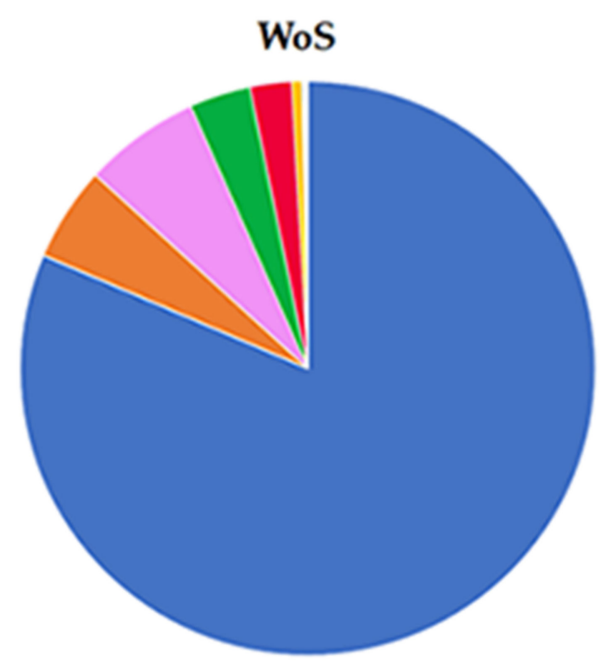

(b)

Figure 1. Pie charts of the document types of all the published papers obtained with the "aerobiology" search in Scopus (a) and Web of Science (WoS) (b) up to 18 June 2020. These results consider every year of publication, from the date of the first published article (1938) to 18 June 2020.

Concerning the year-by-year trend of publications using the single aerobiology keyword (Figure 2), the oldest paper found was published in 1938 [77] and was present only in the Scopus database. In this regard, it is important to underline that, unlike Scopus and PubMed, the WoS database does not contain any records published prior to the year 1985. Considering the aims of this study, WoS is still useful to study the trends in this field of search in the last 30 years.

Before 1990, a small number of papers were recorded (Table 2) with a total number of 136 pre-1990 articles in Scopus (9.58\% of the total) and 52 in PubMed (18.44\% of the total). A sudden increase in the number of papers could be detected in Scopus and WoS starting from the year 1991, with 29 publications for Scopus and 15 for WoS, compared to nine and zero, respectively, for the year 1990. This increase marks the start of an upward trend going on for the 1990-1999 decade, with some rises and falls. The following decades show a similar trend, with some notable relative falls, such as the year 2003 for both Scopus and WoS, and the years 2007 and 2009, mainly for Scopus. In PubMed the trend was different, with just a slight increase from 1997 to 2000, followed by a slow decrease ending in 2007, with a clear upward trend starting in 2008 and going on up to 2019. A relevant spike 
could be observed for 2019, which marked the year with the highest amount of published papers for all the databases: 83 for Scopus, 69 for WoS and 31 for PubMed. Looking at the general trend of the three decades (Table 2), all databases showed upward trends in the number of articles, with a gradual increase in Scopus (+34.7\% from 1990-1999 to 2000-2009 and +38.2\% from 2000-2009 to 2010-2019), a more remarkable upward trend in WoS $(+107.6 \%$ and $+102.4 \%$ respectively) and an even steeper one in PubMed $(+130 \%$ and $+356.5 \%$ respectively). The slower percentage increase in Scopus, compared to the other two databases, can be explained by the higher number of articles in the first decade (1990-1999), while WoS and especially PubMed started with very few articles and had a more recent increase. As this initial overview of the publication history in aerobiology shows that most of the retrieved papers were published after the year 1990, the rest of this study focuses on the analysis of publications from 1990 to 2019.

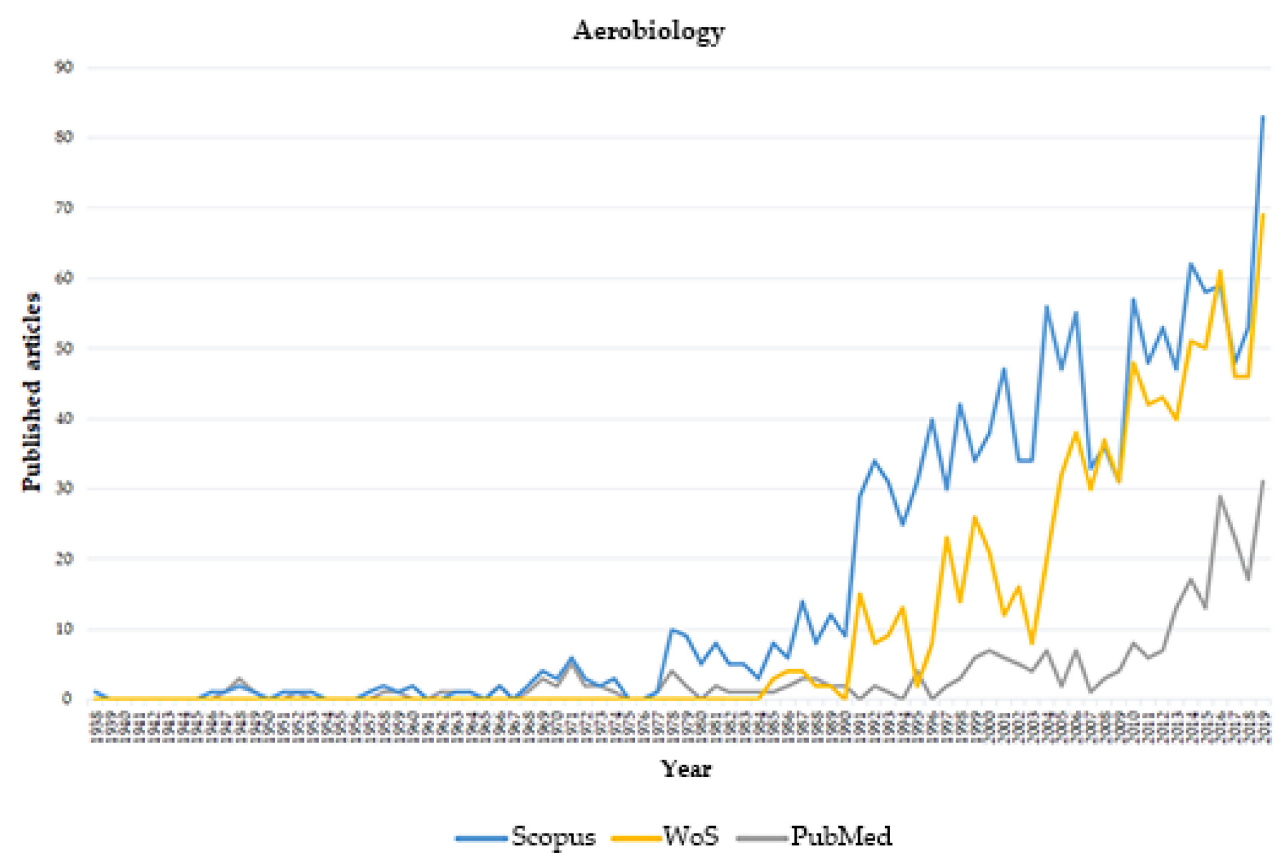

Figure 2. Number of published papers (y-axis) for each year (x-axis) in the three databases. Years from 1938 to 2019.

Table 2. Number of papers in the four different time intervals considered in the study. In brackets are the percentages of papers published in each time period compared to the total. Pre-1990 values are not directly comparable among databases, since WoS only contains articles published starting from 1985.

\begin{tabular}{ccccc}
\hline Database & Pre-1990 & $\mathbf{1 9 9 0 - 1 9 9 9}$ & $\mathbf{2 0 0 0 - 2 0 0 9}$ & $\mathbf{2 0 1 0 - 2 0 1 9}$ \\
\hline Scopus & $136(9.58 \%)$ & $305(21.48 \%)$ & $411(28.94 \%)$ & $568(40 \%)$ \\
WoS & $15(1.72 \%)$ & $118(13.5 \%)$ & $245(28.03 \%)$ & $496(56.75 \%)$ \\
PubMed & $52(18.44 \%)$ & $20(7.09)$ & $46(16.31 \%)$ & $164(58.16 \%)$ \\
\hline
\end{tabular}

\subsection{Research Areas}

Concerning the research areas of papers, in Scopus (Figure 3a) the main area was "Agricultural and Biological Sciences", which showed the highest values in the three decades, with a gradually increasing number of papers (227 in 1990-1999, 232 in 2000-2009, 270 in 2010-2019). A similar pattern could be observed for the area "Medicine" (202, 204, 243), while for "Immunology and Microbiology" $(173,153,191)$ there was a decrease of articles in 2000-2009, followed by a detectable increase in 2010-2019. A very high increase in numbers could be observed for "Environmental Science", with 35, 111 and 210 papers published in the three decades. This remarkable increase, with a $+217.1 \%$ articles from 1990 1999 to $2000-2009$, and $+89.2 \%$ from 2000-2009 to 2010-2019, much higher than the general 
increase in aerobiology in the Scopus database $(+34.7 \%$ and $+38.2 \%$ respectively), indicates that this subject area was the main contributor for the increase of the number of articles in aerobiology in this database. A rise was also clear for "Earth and Planetary Sciences" (number of papers: 19,41,76). All the other subject areas showed a very small number of papers, except for "Biochemistry, Genetics and Molecular Biology", with 29 papers in 2000-2009 and 37 in 2010-2019. In Scopus there is no subject area clearly dedicated to occupational studies.

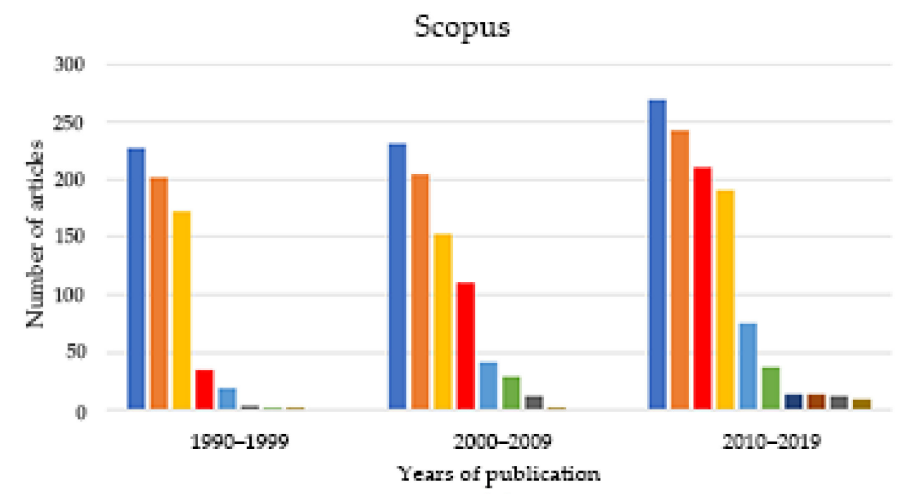

(a)

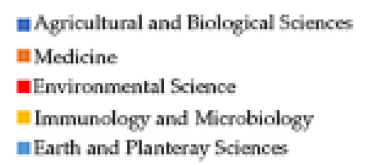

Eiochemistry, Genetics and Molecular Biology nChemistry

- Social Sciences

Engineering

nharmacology, Toxicology and Pharmaceutics

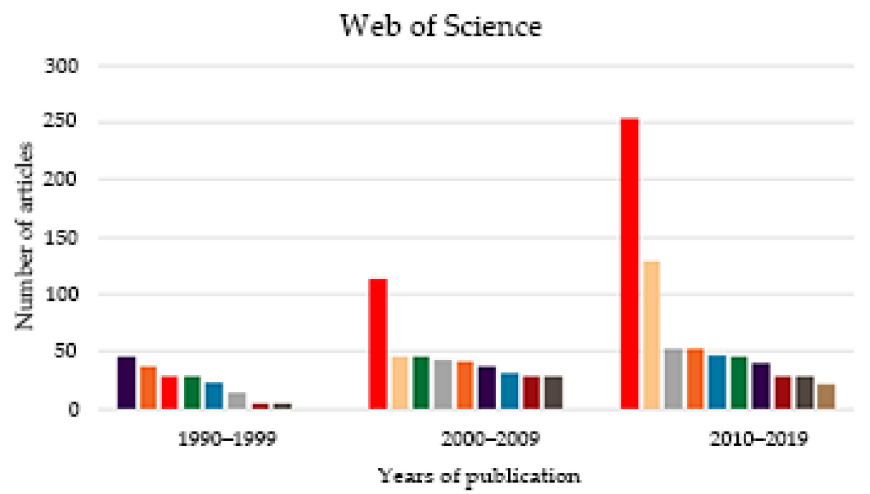

(b)

\begin{tabular}{|c|c|}
\hline $\begin{array}{l}\text { Environmental Sciences } \\
\text { Biology }\end{array}$ & $\begin{array}{l}\text { EPlant Sciences } \\
\text { - Immunology }\end{array}$ \\
\hline $\begin{array}{l}\text { Meterology and Atmospheric Sciences } \\
\text { Alengy }\end{array}$ & $\begin{array}{l}\text { EBiophysics } \\
\text { E Physiology }\end{array}$ \\
\hline Public Environmental Occupati & Microbiology \\
\hline
\end{tabular}

Figure 3. Bar graphs of the number of articles for each research area, obtained with the "Aerobiology" search in Scopus (a) and WoS (b), grouped in three different decades: 1990-1999, 2000-2009 and 2010-2019. Only the ten categories with the highest number of articles are represented.

The results obtained with WoS were notably different (Figure 3b), probably because of the different criteria of classification compared to Scopus, thus making a direct comparison between the two databases only possible via an in-depth reading of the papers. A sensible shift in interest in the last three decades could be observed in WoS. "Immunology" was the field in which most of the articles belonged to for the years 1990-1999, but its predominance notably vanished in the following decades, with the number of articles slightly decreasing, while remaining mostly constant $(45,37,40)$. A similar stable pattern could be observed for the "Allergy" field, with the total number of published papers slightly increasing over time $(37,41,52)$. On the other hand, two fields showed a notable increase of interest. The main one was "Environmental Sciences", rising from an initial number of 29 articles in 1990-1999 to 113 in 2000-2009 and 254 in 2010-2019, making it the most important 
field in the last two decades. This trend reflects the "Environmental Science" field in Scopus (Figure 3a) and confirms that this area of research has shown a considerable development in recent years. In this case, the percentage of increase of the articles $(+289.6$ and +124.8$)$ was higher than the overall increase in aerobiology $(+107.6 \%$ and $+102.4 \%)$, and was mainly reported in the 2000-2009 decade, keeping very high in 2010-2019. The second highest trending field was "Biology", increasing to a maximum of 129 in 2010 2019, despite being zero in 1990-1999. The articles related to the "Biology" field in WoS were mostly included in the stable trending "Agricultural and Biological Sciences" field in Scopus. "Plant Sciences" showed an increase in the number of articles in the second decade compared to the first one, with the number stabilizing in the third decade (28 in 1990-1999, 45 in 2000-2009, 46 in 2010-2019). A more gradual rise could be observed for the field of "Public, Environmental and Occupational Health", passing from 23 articles (1990-1999) to 31(2000-2009) and 47 (2010-2019), respectively. These values show that the interest towards the application of aerobiological studies to occupational and public health has been generally quite low if compared with other categories, and is increasing at a slow rate (mean increase from decade to decade $=43.1 \%$ ) if compared with the general trend of aerobiology (mean increase $=105 \%$ ). A very similar trend was found in "Meteorology and Atmospheric Sciences" $(14,42,53)$. An interesting parallel was observed for "Biophysics" $(4,29,29)$ and "Physiology" $(4,28,28)$, both almost absent in 1990-1999 but stable in the following decades.

PubMed was not included in the scoping of the categories, since it does not have a classification system comparable with the other two databases.

\subsection{Networks and Emerging Research Trends}

\subsubsection{Categories}

The network based on the "Category" node type (Figure 4) and constructed on WoS data showed the predominance of the "Environmental Sciences" category, which was the most widely selected with 389 articles and was the center of gravity of the network, with a very high betweenness centrality value of 1.00. Betweenness centrality (or just "centrality" in this paper) measures how much a node is a part of paths that connect any other two nodes of the network [78]. Other categories with high counts of papers and high centrality were "Meteorology and Atmospheric Sciences" (count $=105$, centrality $=0.60$ ), and "Public, Environmental and Occupational Health" (count = 98, centrality = 0.81). These were pivotal categories in aerobiology, including many articles and connecting different disciplines. "Immunology" (count $=92$, centrality $=0.47$ ) and "Plant Sciences" (count $=112$, centrality $=0.36$ ) had high counts and medium centrality. Other categories showed a high count of articles coupled with a very low centrality, the main ones being "Biology" (count $=175$, centrality $=0.00)$, "Allergy" (count $=104$, centrality $=0.13$ ) and "Physiology" (count $=56$, centrality $=0.00$ ). These categories contained articles about topics that polarize much attention but are confined in their own subject, not interconnecting with other topics in aerobiology. Some categories, on the other hand, showed a very low number of publications but had a relatively good value of centrality. Examples are "Forestry" $($ count $=13$, centrality $=0.53)$, "Agronomy" $($ count $=24$, centrality $=0.44)$ and "Ecology" (count $=17$, centrality $=0.36)$.

Regarding clustering, the detailed results are reported in the Supplementary Materials (Table S1). The widest cluster (cluster \#0) contained some of the most abundant and central categories, such as "Environmental Sciences", "Biology", "Meteorology and Atmospheric Sciences" and "Biophysics", with its top terms (based on keywords log-likelihood analysis) being "arid regions", "vegetation history" and "volumetric sampling", underlining the predominance of volumetric sampling methods in this kind of subject. Cluster $\# 0^{\prime}$ s silhouette index was 1, indicating a very homogenous group. Silhouette is an index of the homogeneity and reliability of a cluster, ranging between 0 and 1, with 1 being the maximum value, and 0.5 being considered a good value for a cluster to be regarded as reliable $[79,80]$. Cluster \#1 (silhouette = 1) included "Plant Sciences", "Agronomy" and "Forestry" as main 
nodes, and "vineyards", "atmospheric scale" and "downy mildew" as top terms, indicating a cluster of articles focused on farming-related topics, such as crops parasites. Cluster \#2 (silhouette =1) contained "Allergy" and "Immunology", with "asthma", "skin test" and "chickens" as top terms, indicating a cluster focused on the effect of aerobiological particles on human health. Another relevant one is cluster \#4 (silhouette $=0.921$ ), which contained the large "Public, Environmental and Occupational Health" as its main node, grouped with three other very small nodes with 0 centrality: "Infectious Diseases", "Engineering Environmental", "Construction and Building Technology". The top terms of this cluster were "pollution", "particles" and "conservation". These results show that "Public, Environmental and Occupational Health" was closely related only to small niche subjects, despite its importance in the overall structure of the network, as proven by its high centrality (0.81).

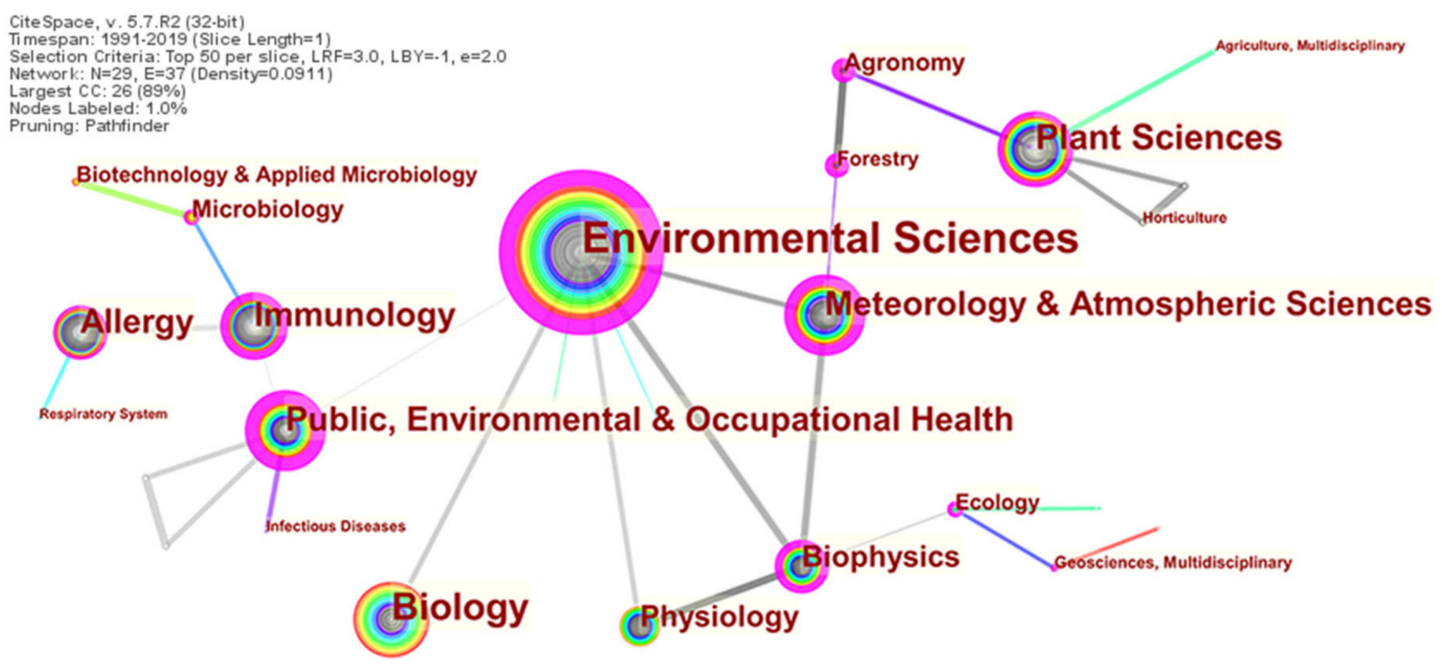

Figure 4. Network of co-occurring WoS categories (years 1990-2019). The colors of the rings in each node indicate a different year. The purple external rings indicate a high betweenness centrality value of the node.

The results of the burstness analysis are reported in the Supplementary Materials (Figure S1). The strongest bursts were related to "Immunology" (strength = 19.02), lasting from 1992 to 2004, and "Allergy" (strength = 10.31), spanning from 1992-1999. This result indicates that the two subjects have been a focus of interest since the beginning of the considered time period, being the most important categories in the 1990s. "Public, Environmental and Occupational Health" showed a burst (strength = 5.46) starting in 1994 and ending in 1997, a short burst confined to the first decade of concern, not repeated in the following ones, underlining that the interest in this category has not sensibly increased in recent years. In the early 2000s, "Plant Sciences, Meteorology and Atmospheric Sciences", "Physiology", "Biophysics" and "Agronomy" were involved in relevant bursts, while in more recent years other disciplines showed significant increases of interest, like "Ecology" (strength $=3.45,2014-2015)$ and, especially, "Microbiology" (strength $=4.91,2016-2019)$ and "Biotechnology and Applied Microbiology" (strength = 4.03, 2016-2019), whose bursts reached the end of the considered time period, meaning that they are currently hot topics.

\subsubsection{Countries}

The network constructed on countries (Figure 5) showed Spain as the most prolific country, with 243 publications, followed by the USA (174), England (78), Italy (67), Poland (56), France (48) and Canada (33). Other countries had less than 30 articles. Regarding centrality, the highest values were associated with England (0.77), Austria (0.55), Denmark (0.54), France (0.49), Netherlands (0.28) and Spain (0.27). These countries often collaborate with other countries and are a relevant link in the international aerobiological community. Regarding clustering (Table S2), France, Canada and Germany were the main components of cluster \#0 (silhouette $=0.846$, while the second main cluster $(\# 1$, silhouette $=0.832)$ in- 
cluded England and Denmark, two countries with very high centrality. Another interesting cluster, including various high publishing countries, was \#4 (silhouette =1), containing Italy, Poland and Portugal. The two countries with the most publications, Spain and USA, were confined to very small clusters, where they were grouped with countries with low numbers of publications. Regarding burstness (Figure S2), four countries showed a relevant increase in publications over the course of a few years, the first two being Canada (strength $=5.27,1999-2006$ ) and USA (strength $=6.94,2000-2006$ ), indicating an increase of interest towards aerobiology in North America in the early 2000s, followed by a sudden increase of publications for Croatia (strength $=5.1,2004-2016$ ), whose significance is questionable, considering it was one of the countries with the lowest number of publications (count $=11)$. The latest burst was related to Germany (strength $=6.94,2017-2019$ ).

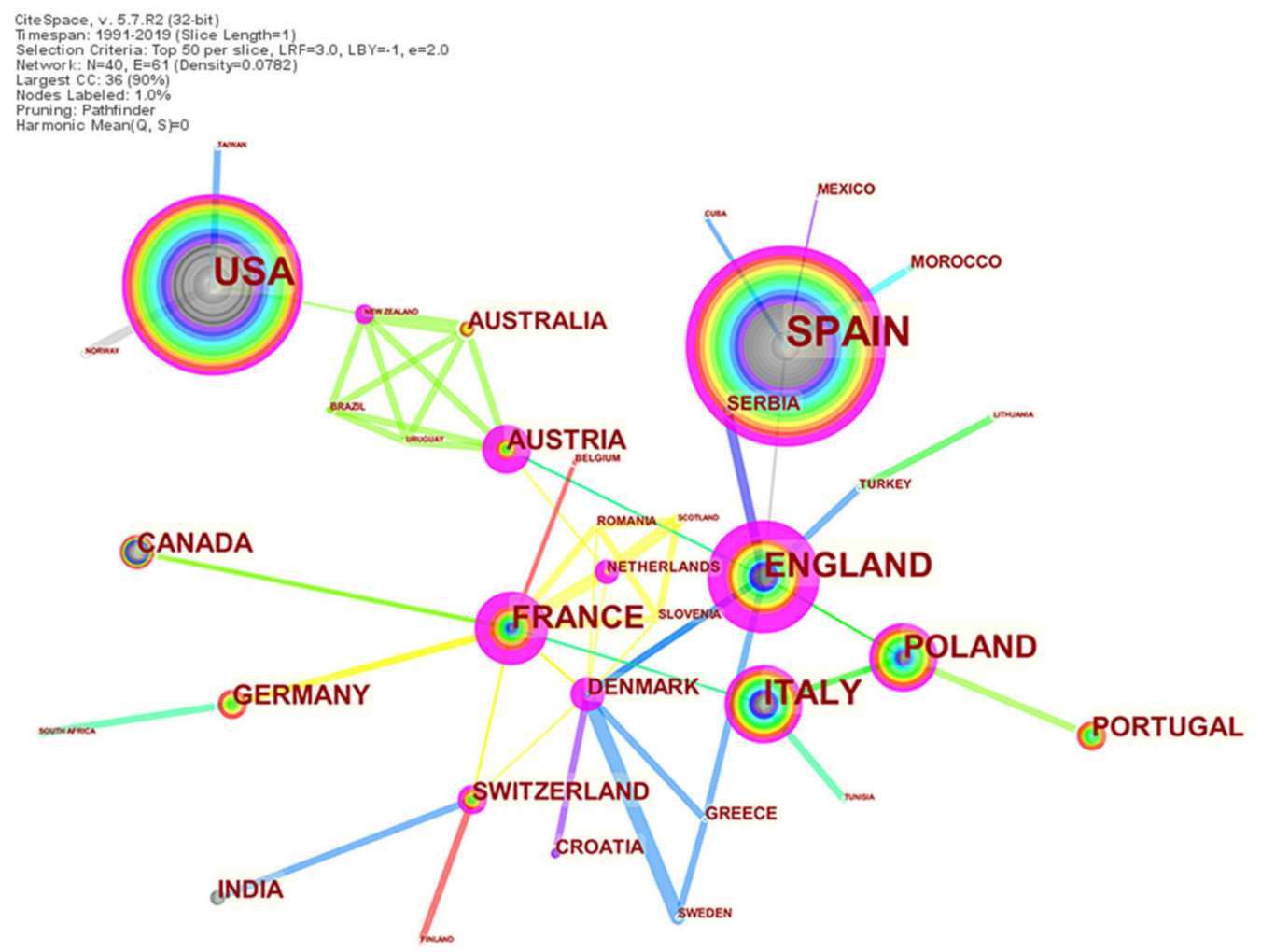

Figure 5. Network of collaborating countries (years 1990-2019). The colors of the rings in each node indicate a different year. The purple external rings indicate a high betweenness centrality value of the node.

\subsubsection{Keywords}

Regarding the keywords network (Figure 6), the most represented keyword was "aerobiology" (count $=555$ ), a very predictable result considering it was the search input in the databases, and thus it was not considered thoroughly for the interpretation of results. Among others, the most represented keywords were "pollen" (113), "allergy" (65), "phenology" (42), "airborne pollen" (27), "climate change" (27), "fungal spore" (24), "meteorological parameter" (23), "bioaerosol" (23), "asthma" (20), "aeroallergen" (15), "fungi" (12), "pollen allergy" (12), "pollen calendar" (13), "aerosol" (12) and "meteorology" (10). Regarding centrality, the highest values were found for "pollen" (0.55), "asthma" (0.40), "allergy" (0.35), "meteorology" (0.27), "fungal spore" (0.23) and "airborne pollen" (0.20). All other keywords had centrality values lower than 0.20 . The resulting clusters (Table S3) showed some very large groups containing a high number of different keywords. Cluster \#0 (silhouette $=0.831$ ) was the most important, being composed of "pollen" in addition to "aeroallergen", "pollen calendar", "allergen" and "meteorology". The top terms of the cluster were "pollinosis", "ole e 1" and "atmospheric pollen", making this 
the general pollen cluster. Cluster \#1 (silhouette = 0.917) contained "allergy", "airborne pollen" and "climate change", with its top terms being "skin-prick test", "Spain" and "predictive models". This is an interesting result, considering that climate change is one of the emerging topics in many disciplines. Its inclusion in this cluster suggests that, in aerobiology, this topic is explored in relation to the dispersion of pollen and after that in relation to the effects on human health. Given the rising importance of this topic, its further exploration in aerobiology is likely to be a promising research line for the future. Other notable groups were for "aerobiology", cluster \#5 (silhouette =1), and cluster \#6 (silhouette $=0.822$ ), containing "asthma", "pollen allergy" and "pollinosis". Only four keywords showed a relevant citation burst (Figure S3), mostly belonging to the last decade: "allergy" (strength = 4.14, 2009-2012), "fungi" (strength = 3.84, 2011-2016), "meteorological parameter" (strength $=5.9,2013-2016)$ and "bioaerosol" (strength $=7.09,2017-2019)$.

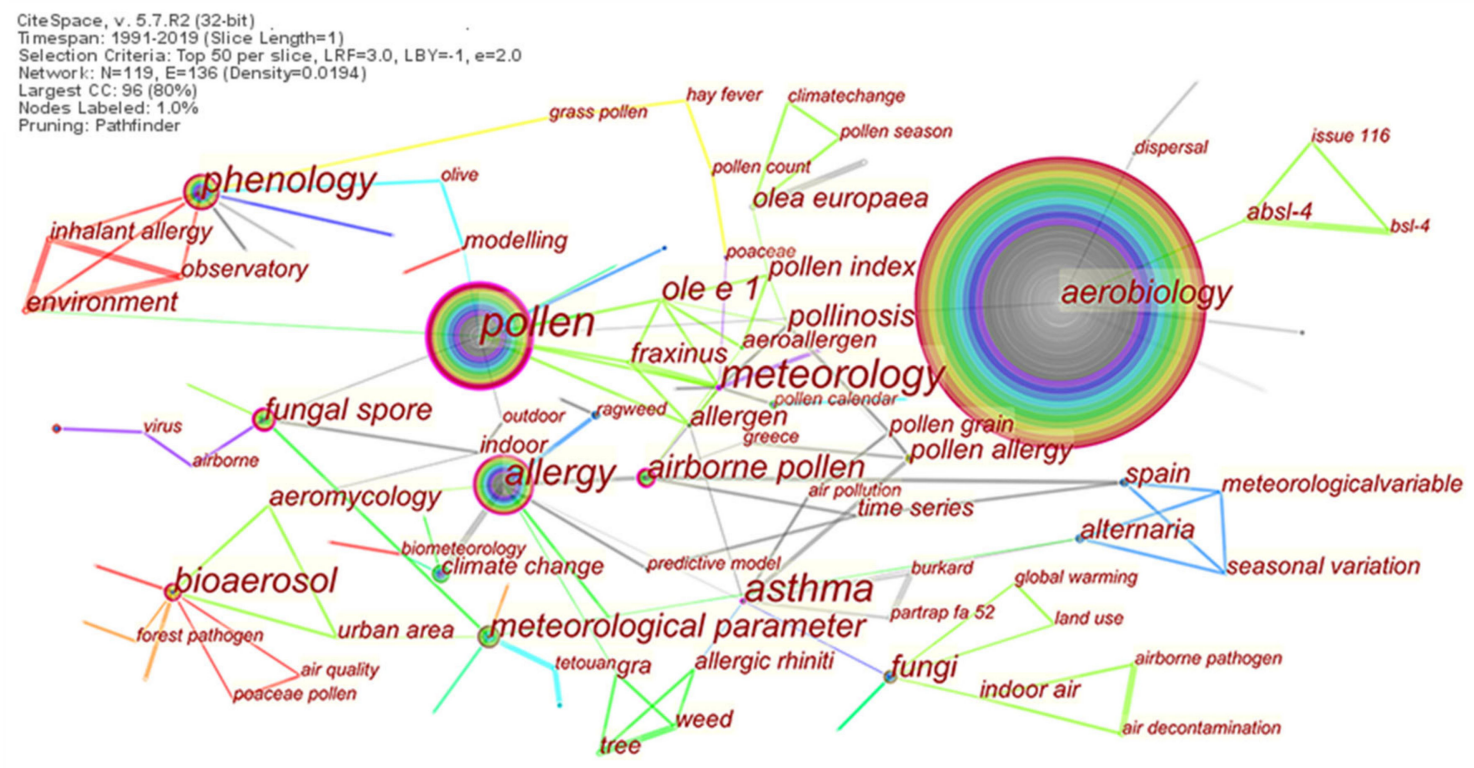

Figure 6. Network of co-occurring keywords (years 1990-2019). The colors of the rings in each node indicate a different year. The purple external rings indicate a high betweenness centrality value of the node.

\subsubsection{Additional Remarks}

The topic of climate change (Table 1) in relation to aerobiology accounted for a total of 190 articles extracted from the three databases over the entire period considered, thus representing a minor part of the literature concerned. The possibility that features related to climate change were present in at least some of the articles found using the search term aerobiology AND climate, which were more abundant in the literature, cannot be excluded. However, this does not change the general picture. In fact, the keyword "climate change" displayed a low centrality value ( 0.08 , see Table S3) and was little represented in the network of co-occurring keywords (Figure 6). Moreover, it was connected only with "allergy" and, to a lesser extent, with "fungal spores". It may be argued that climate change, a topic that literally exploded in the last two decades in terms of its impact on natural environments and human activities and health, is still little explored on the side of several topics relating to aerobiology.

A topic displaying an even more marginal importance, as it emerged in this study, was the occupational one. In fact, the search input aerobiology AND occupational produced only 54 articles for the three databases over the whole period concerned. Moreover, it was possible to categorize this topic only for the WoS database (Figure 3), including it in the more comprehensive category "Public Environmental and Occupational Health", which displayed just a modest increase in terms of publications during the three decades of concern. Furthermore, in the network of co-occurring WoS categories (Figure 4), "Public, 
Environmental and Occupational Health" was poorly connected with other categories, even if it showed a high value of centrality (0.81, see Table S1). This result is not surprising as occupational allergies due to pollen and fungal spores were a subject of increasing interest in the last decades and produced a large number of studies. This is also in line with the activity of national and international institutions in the field of aerobiology, often privileging aeroallergens. Research in occupational health, although not restricted to this (as stated in the introduction), has not yet fully taken into account other aerobiological topics. However, the extensive definition of aerobiology given in the introduction should encourage researchers in occupational health and safety to explore other topics related to this subject.

\section{Conclusions}

The results of this bibliometric analysis demonstrate that aerobiology is receiving increasing interest, with the number of publications showing an upward trend in the last years. Not all research areas in aerobiology are increasing at the same rate; in particular, in the most recent decades, there has been a shift of interest towards environmental sciences, while other subjects that were predominant in the nineties, especially allergy and immunology, have remained stable compared to the overall rise of the entire discipline. The networks show aerobiology as a multidisciplinary science, including categories related to environmental sciences, such as plant sciences and meteorology, but also health-related categories, like allergy and immunology. The most active countries publishing in this field are Spain and USA, with several European countries being important linkage nodes, mainly England, Austria, Denmark and France. The analysis of keywords showed that studies on pollen are the most abundant, in particular those related to the effects of pollen on human health. Regarding other types of biological particles, fungal spores have been a subject of interest too, due to their connection with plant diseases, while bacteria, viruses and other organisms are not well-represented. Occupational exposure to airborne biological agents or airborne biologically derived material is a crucial issue in many settings, both outdoors and indoors. As the dynamics of air transport of biological or biologically derived particles, including the cases of outdoor-indoor exchanges, may be studied in an integrated way in workplaces, it is time to regard this matter as a subset of occupational health and safety, for which the term "Occupational Aerobiology", encompassing all relevant features, could be proposed. This new discipline, if properly understood and managed, could disclose new perspectives on biological risk.

Climate change is largely recognized as a main threat for natural environments and human societies. The International Panel of Climate Change $[81,82]$ and other national and international organizations deal with periodic assessments of the potential impact of climate change, proposing and discussing mitigation and adaption measures at international, national, local and individual level. Climate change is recognized to impact human health both directly and indirectly in terms of increased mortality and morbidity, the patterns of which are largely dependent on the types and extent of related phenomena (heatwaves, extreme events, etc.), geographical location, target population and economic and social determinants [83-85]. Occupational health is also affected by climate change [86,87] in terms of heat stress and effects on productivity $[88,89]$, as well as regarding work-related injuries [90]. However, climate change and occupational health are beginning to be explored from other points of view [91], including occupational exposure to solar radiation [92], vector-borne diseases in working populations [93] and occupational allergies [94]. In the light of the aims of this work, the scenario reported here stresses the importance of strengthening the research activity at the interface between aerobiology, occupational health and climate change.

Considering the wide variety of airborne biological and biologically derived components in workplaces and recognizing that each working setting/activity may be characterized by different and time-changing patterns of exposure, it is of great importance to identify suitable biomarkers of exposure/effects. The concept of "exposome" may be useful 
in this regard [95], as it relates to the identification and quantification of "all" exposures an individual experiences during their lifecycle, starting from prenatal life. The occupational exposure to airborne biological material may be "a piece" of the individual exposome. However, although the concept of exposome is expanding and its potential is increasingly recognized [96-98], its use in exposure assessment and occupational health practice is still beyond the current operative tools.

At the same time, it is equally important to define the individual profiles of susceptibility to aerobiological agents found in both outdoor and indoor workplaces. The usefulness of defined categories of susceptibility (e.g., pregnancy, advanced age or immune depression), although essential, is limited in this regard, as susceptibility represents a biological continuum, the details of which are often largely unknown or, when known, are too difficult to apply in health surveillance or other occupational health practices.

The development of high throughput "omics" approaches in aerobiology (including proteomics, metabolomics and the new and rapidly expanding field of epigenomics) is equally important with respect to many other branches of biology and medicine. Apart from the costs, the most critical concerns are given by the integration, interpretation and, ultimately, the application of multi-omics data $[99,100]$. However, the rapid advances in the "omics" tools and the management of "big data", as well the development of single-cell omics applications [101], will disclose many opportunities in occupational aerobiology. Although molecular and innovative methodologies have been utilized in recent years for the evaluation of different biocomponents in aerosols [102-110], analytical techniques such as portable pollen samplers $[109,111,112]$ and flow cytometry $[113,114]$, should be improved in order to expand the development of aerobiology. In this regard, their application in occupational settings assumes great importance $[10,115]$, and they could also be aimed at investigating the role of occupants with regard to the transport of bioparticles using a multidisciplinary approach. An innovative integrate approach should also be applied, adopting real-time sampling of bioaerosols that is able to select pollen, in association to the monitoring of meteorological parameters, such as solar radiation, relative humidity and temperature [116].

Several epidemiological and experimental studies reported a significant interaction between allergens and air pollutants in urban and industrial environments. The increasing concentrations of environmental pollutants should be studied in relation to airborne particles exposure to evaluate synergistic effects on health. Several outdoor atmospheric pollutants of different origins—-such as particulate matter $\left(\mathrm{PM}_{10}, \mathrm{PM}_{2.5}\right)$, carbon dioxide, ozone, sulfur dioxide and nitrogen oxides-derived from anthropogenic activities and the effect of the "urban heat island" in urban areas may affect airborne particles properties (e.g., alterations in protein composition and structure result in a higher allergenic potential of pollen and increases in the amount of aerobiological particles released and dispersed), increasing the risk of development and/or exacerbation of allergic diseases [117-122].

Recently, pollen has been identified as a predictor of the inverse seasonality of flulike epidemics and as involved in changes in lung functions [123-125]. Moreover, an association between pollen levels and cancer incidence has been proposed, suggesting that, for different so-called specific intractable diseases (SIDs), pollen might be one the agents able to influence important pathways of the vital functions and metabolisms in various organs, although epidemiological studies are necessary [126].

Another viable development of aerobiological research could be a more extensive and comprehensive evaluation of the geographical layout of the sources of aerobiological particles. Prominent tools in this field could be vegetation maps, which have proven to be useful instruments in the study of exposure to pollen [127]. For example, the application of vegetation maps can be used to understand which pollen types come from proximal or distal sources and how they are influenced by wind direction [128], or how the land cover can affect the length and intensity of human exposure to pollen [129]. In addition, tree and grass coverage can be correlated to pollen abundance and health effects on the population [130-132]. 
Further research should better investigate potential synergistic effects between aerobiological particles and other factors by improving the innovative techniques of monitoring and analysis, thus extending the application of aerobiology in the management of occupational health.

Supplementary Materials: The following are available online at https: / www.mdpi.com/article / 10.3390/su13084337/s1, Table S1: List of WoS categories (years 1990-2019), grouped in different clusters. Top terms are based on keyword log-likelihood ratio (LLR). Top terms are presented in the same format as the CiteSpace output, entirely in lowercase letters. Silhouette: value indicating the homogeneity of the cluster; mean year: mean year of publication; count: number of articles belonging to the category; centrality: value indicating how much a node is part of paths connecting other nodes; Table S2: List of the most important publishing countries (years 1990-2019), grouped in different clusters. Top terms are based on keyword log-likelihood ratio (LLR). Countries and top terms are presented in the same format as the CiteSpace output, entirely in uppercase or lowercase letters. Silhouette: value indicating the homogeneity of the cluster; mean year: mean year of publication; count: number of articles belonging to the country; centrality: value indicating how much a node is part of paths connecting other nodes; Table S3: List of the most represented keywords (years 1990-2019), grouped in different clusters. Top terms are based on keyword log-likelihood ratio (LLR). Keywords are presented in the same format as the CiteSpace output, with no uppercase letters and no italics. Silhouette: value indicating the homogeneity of the cluster; mean year: mean year of publication; count: number of articles that contain the keyword; centrality: value indicating how much a node is part of paths connecting other nodes; Figure S1: List of categories with the strongest citation bursts (years 1990-2019). The red segments indicate the years of the burst. Year: starting year of the analysis; strength: intensity of the burst; begin/end: initial and final year of the burst; Figure S2: List of countries with the strongest citation bursts (years 1990-2019). The red segments indicate the years of the burst. Year: starting year of the analysis; strength: intensity of the burst; begin/end: initial and final year of the burst; Figure S3: List of keywords with the strongest citation bursts (years 1990-2019). The red segments indicate the years of the burst. Year: starting year of the analysis; strength: intensity of the burst; begin/end: initial and final year of the burst.

Author Contributions: Conceptualization: A.L.; D.M. and M.C.D.; methodology: A.L.; C.G.; D.M. and M.C.D.; formal analysis: A.L.; D.M. and M.C.D.; investigation: A.L.; P.C.; D.M. and M.C.D.; data curation: A.L.; P.C.; N.V.; A.P.; C.G.; D.M. and M.C.D.; writing-original draft preparation: A.L.; P.C.; N.V.; C.G.; D.M. and M.C.D.; writing-review and editing: A.L.; P.C.; N.V.; A.P.; C.G.; D.M. and M.C.D.; visualization: A.L.; D.M. and M.C.D.; supervision: A.P.; D.M. and M.C.D.; project administration: D.M. and M.C.D. All authors have read and agreed to the published version of the manuscript.

Funding: This research was carried out in the frame of INAIL (Italian Workers' Compensation Authority) researches.

Institutional Review Board Statement: Not applicable.

Informed Consent Statement: Not applicable.

Data Availability Statement: Not applicable.

Conflicts of Interest: The authors declare no conflict of interest.

\section{References}

1. Fernstrom, A.; Goldblatt, M. Aerobiology and Its Role in the Transmission of Infectious Diseases. J. Pathog. 2013, 2013, 1-13. [CrossRef] [PubMed]

2. Khandelwal, A. Aerobiology: Aspects and prospects. Palaeobotanist 2008, 57, 251-255.

3. Beggs, P.J.; Šikoparija, B.; Smith, M. Aerobiology in the International Journal of Biometeorology, 1957-2017. Int. J. Biometeorol. 2017, 61, 51-58. [CrossRef] [PubMed]

4. Gregory, P.H. The Microbiology of the Atmosphere; Leonard Hill: London, UK, 1961.

5. Lacey, M.E.; West, J.S. The Air Spora: A Manual for Catching and Identifying Airborne Biological Particles; Springer: Dordrecht, The Netherlands, 2006.

6. Mandrioli, P.; Ariatti, A. Aerobiology: Future course of action. Aerobiology 2001, 17, 1-10. [CrossRef]

7. Cox, C.S. The Aerobiological Pathway of Microorganisms; John Wiley \& Sons: Chichester, UK, 1987. [CrossRef] 
8. Kapadi, M.R.; Patel, S.I. Aeromycological approach of some fungal diseases on Tomato Crop (Lycopersicon esculentum Mill.) at Nashik, India 422007. J. Drug Deliv. Ther. 2019, 9, 329-331. [CrossRef]

9. Burge, H.A. An update on pollen and fungal spore aerobiology. J. Allergy Clin. Immunol. 2002, 110, 544-552. [CrossRef]

10. Pelliccioni, A.; Monti, P.; Cattani, G.; Boccuni, F.; Cacciani, M.; Canepari, S.; Capone, P.; Catrambone, M.; Cusano, M.; D'Ovidio, M.C.; et al. Integrated Evaluation of Indoor Particulate Exposure: The VIEPI Project. Sustainability 2020, 12, 9758. [CrossRef]

11. Dobell, C. Antony Van Leewenhoek and His 'Little Animals; Bale \& Danielsson: London, UK, 1932.

12. Buller, A.H.R. Micheli and the discovery of reproduction in fungi. Trans. R. Soc. Can. 1915, 9, 1-25.

13. Moreau, R. The origin of aerobiology. J. Aerosol Sci. 1994, 25, 109-110. [CrossRef]

14. Maddox, R.L. On an Apparatus for collecting Atmospheric Particles. Mon. Microsc. J. 1870, 3, 286-290. [CrossRef]

15. Cunningham, D.D. Microscopic Examinations of Air; Government Printer: Calcutta, India, 1873.

16. Miquel, P. Les Organismes Vivants de l'Atmosphère; Gauthier-Villars: Paris, France, 1883.

17. Blackley, C. Experimental Researches On the Cause and Nature Of Catarrhus Aestivus (Hay Fever, Hay Asthma); Balliere, Tindall \& Cox: London, UK, 1873.

18. Hesse, W. Ueber quantitative Bestimmung der in der luft enthaltenen mikroorganismen. Mitth. Kaiserl. Gesundh. 1884, 2, 182-207.

19. Hesse, W. Bemerkungen zur quantitative bestimmung der mikroorganismen in der luft. Z. Hyg. InfektKrankh. 1888, 4, $182-207$.

20. Frankland, P.F. The distribution of microorganisms in air. Proc. R. Soc. 1886, 40, 506-526. [CrossRef]

21. Frankland, P.F.; Hart, T.G. Further experiments on the distribution of microorganisms in air (by Hesse's method). Proc. R. Soc. 1887, 42, 267-282. [CrossRef]

22. Durham, O.C. Air-borne fungus spores as allergens. In Aerobiology; Moulton, F.R., Ed.; American Association for the Advancement of Science: Washington, DC, USA, 1942; pp. 32-47.

23. Boehm, G. Aerobiology-Its Past and its Future. Galanin 1987, 51, 3-8. [CrossRef]

24. Haskell, R.J.; Barss, H.P. Fred Campbell Meier, 1893-1938. Phytopathology 1939, 29, $293-302$.

25. Moulton, F.R. Foreword. In Aerobiology; Moulton, F.R., Ed.; American Association for the Advancement of Science: Washington DC, USA, 1942; p. iii.

26. Hyde, H. Volumetric counts of pollen grains at Cardiff, 1954-1957. J. Allergy 1959, 30, 219-234. [CrossRef]

27. Hyde, H. Studies in atmospheric pollen. IV. Pollen deposition in Great Britain, 1943. Part II. The composition of the pollen catch. New Phytol. 1950, 49, 407-420. [CrossRef]

28. Hyde, H.; Williams, D. Studies in atmospheric pollen. II: Diurnal variation in the incidence of grass pollen. New Phytol. 1945, 44, 83-94. [CrossRef]

29. Gregory, P.H. Spore Content of the Atmosphere Near the Ground. Nat. Cell Biol. 1952, 170, 475-477. [CrossRef]

30. Hirst, J.M. Philip Herries Gregory: 24 July 1907-February 1986. Biog. Mems. Fell. R. Soc. Lond 1990, 35, 153-177. [CrossRef]

31. Hirst, J.M. Biography of an aerobiologist: P.H. Gregory (1907-1986). Aerobiologia 1992, 8, 209-218. [CrossRef]

32. Gregory, P. The dispersion of air-borne spores. Trans. Br. Mycol. Soc. 1945, 28, 26-72. [CrossRef]

33. Hirst, J.M. An automatic volumetric spore trap. Ann. Appl. Biol. 1952, 39, 259-265. [CrossRef]

34. Perkins, W.A. The Rotorod Sampler, 2nd ed.; Semiannual Report; Aerosol Laboratory, Department of Chemistry and Chemical Engineering, Stanford University: Stanford, CA, USA, 1957.

35. Buters, J.T.; Antunes, C.; Galveias, A.; Bergmann, K.C.; Thibaudon, M.; Galán, C.; Schmidt-Weber, C.; Oteros, J. Pollen and spore monitoring in the world. Clin. Transl. Allergy 2018, 8, 9. [CrossRef]

36. Brennan, G.L.; Potter, C.; de Vere, N.; Griffith, G.W.; Skjøth, C.A.; Osborne, N.J.; Wheeler, B.W.; McInnes, R.N.; Clewlow, Y.; Barber, A. Temperate airborne grass pollen defined by spatiotemporal shifts in community composition. Nat. Ecol. Evol. 2019, 3, 750-754. [CrossRef]

37. Calderon, C.; Ward, E.; Freeman, J.; McCartney, H.A. Detection of airborne fungal spores sampled by rotating-arm and Hirst-type spore traps using polymerase chain reaction assays. J. Aerosol Sci. 2002, 33, 283-296. [CrossRef]

38. Williams, R.H.; Ward, E.; McCartney, H.A. Methods for integrated air sampling and DNA analysis for detection of airborne fungal spores. Appl. Environ. Microbiol. 2001, 67, 2453-2459. [CrossRef]

39. Albertini, R.; Ugolotti, M.; Buters, J.; Weber, B.; Thibaudon, M.; Smith, M.; Galan, C.; Brandao, R.; Antunes, C.; Grewling, L.; et al . The European project HIALINE (health impacts of airborne allergen information network): Results of pollen and allergen of Betula monitoring in Parma (2009). Rev. Allergy Clin. Immunol. 2013, 23, 14-20.

40. Buters, J.T.M.; Thibaudon, M.; Smith, M.; Kennedy, R.; Rantio-Lehtimaki, A.; Albertini, R.; Reese, G.; Weber, B.; Galan, C.; Brandao, R.; et al. Release of Bet v 1 from birch pollen from 5 European countries. Results from the HIALINE Study. Atmos. Environ. 2012, 55, 496-505. [CrossRef]

41. O'Connor, D.J.; Healy, D.A.; Hellebust, S.; Buters, J.T.; Sodeau, J.R. Using the WIBS-4 (Waveband Integrated Bioaerosol Sensor) technique for the on-line detection of pollen grains. Aerosol Sci. Technol. 2014, 48, 341-349. [CrossRef]

42. O'Connor, D.J.; Daly, S.M.; Sodeau, J.R. On-line monitoring of airborne bioaerosols released from a composting/green waste site. Waste Manag. 2015, 42, 23-30. [CrossRef]

43. Fennelly, M.J.; Sewell, G.; Prentice, M.B.; O'Connor, D.J.; Sodeau, J.R. The use of real-time fluorescence instrumentation to monitor ambient primary biological aerosol particles (PBAP). Atmosphere 2018, 9, 1. [CrossRef]

44. Crouzy, B.; Stella, M.; Konzelmann, T.; Calpini, B.; Clot, B. All-optical automatic pollen identification: Towards an operational system. Atmo. Environ. 2016, 140, 202-212. [CrossRef] 
45. Cheng, Y.S.; Barr, E.B.; Fan, B.J.; Hargis, P.J.; Rader, D.J.; O’Hern, T.J.; Torczynski, J.R.; Tisone, G.C.; Preppernau, B.L.; Young, S.A.; et al. Detection of bioaerosols using multiwavelength UV fluorescence spectroscopy. Aerosol Sci. Technol. 1999, 30, 186-201. [CrossRef]

46. Eversole, J.D.; Cary, W.K.; Scotto, C.S.; Pierson, R.; Spence, M.; Campillo, A.J. Continuous bioaerosol monitoring using UV excitation fluorescence: Outdoor test results. Field Anat. Chem. Technol. 2001, 5, 205-212. [CrossRef]

47. Huffman, J.A.; Perring, A.E.; Savage, N.J.; Clot, B.; Crouzy, B.; Tummon, F.; Shoshanim, O.; Damit, B.; Schneider, J.; Sivaprakasam, V.; et al. Real-time sensing of bioaerosols: Review and current perspectives. Aerosol Sci. Technol. 2020, 54, 465-495. [CrossRef]

48. Heikkinen, M.S.A.; Hjelmroos-Koski, M.K.; Häggblom, M.M.; Macher, J.M. Bioaerosols. In Aerosols Handbook: Measurment, Dosimetry and Health Effects; Ruzer, L.S., Harley, N.H., Eds.; CRC Press: Boca Raton, FL, USA, 2005; pp. 291-342. [CrossRef]

49. Andersen, A.A. New sampler for the collection, sizing and enumeration of viable airborne particles. J. Bacteriol. 1958, 76, 471. [CrossRef]

50. Willeke, K.; Lin, X.; Grinshpun, S.A. Improved aerosol collection by combined impaction and centrifugal motion. Aerosol Sci. Technol. 1998, 28, 439. [CrossRef]

51. Emberlin, J.; Baboonian, C. The development of a new method of sampling air-borne particles for immunological analysis. In Proceedings I: Proceedings of the Plenary Sessions, Main Symposia and Afternoon Symposia, Proceedings II: Proceedings of the Free Communications, Proceedings of the XVI European Congress of Allergology and Clinical Immunology, Madrid, Spain, 25-30 June 1995; Basomba, A., Hernandez, M.D., de Rojas, F., Eds.; Monduzzi Editore: Bologna, Italy, 1995; pp. 39-43.

52. Aizenberg, V.; Bidinger, E.; Grinshpun, S.A.; Willeke, K.; Hamed, A.; Tabakoff, W. Airflow and particle velocities near a personal aerosol sampler with a curved, porous aerosol sampling surface. Aerosol Sci. Technol. 1998, 18, 247. [CrossRef]

53. Mainelis, G.; Willeke, K.; Baron, P.; Grinshpun, S.A.; Reponen, T. Induction charging and electrostatic classification of micrometersize particles for investigating the electrobiological properties of airborne microorganisms. Aerosol Sci. Technol. 2002, 36, 479. [CrossRef]

54. Mainelis, G.; Willeke, K.; Adhikari, A.; Reponen, T.; and Grinshpun, S.A. Design and collection efficiency of a new electrostatic precipitator for bioaerosol collection. Aerosol Sci. Technol. 2002, 36, 1073. [CrossRef]

55. Meima, M.; Kuijpers, E.; van den Berg, C.; Kruizinga, A.; van Kesteren, N.; Spaan, S. Biological Agents and Prevention of Work-Related Diseases: A Review; European Agency for Safety and Health at Work (EU-OSHA): Bilbao, Spain, 2020. [CrossRef]

56. Kasprzyk, I. Aeromycology-Main research fields of interest during the last 25 years. Ann. Agr. Env. Med. 2008, 15, 1-7.

57. Cariñanos, P.; Alcazar, P.; Galan, C.; Navarro, R.; Dominguez, E. Aerobiology as a tool to help in episodes of occupational allergy in work places. J. Invest. Allergol. Clin. Immunol. 2004, 14, 300-308.

58. Crook, B. Aerobiological investigation of occupational respiratory allergy in agriculture in the UK. Grana 1994, 33, 81-84. [CrossRef]

59. Lee, S.A.; Liao, C.H. Size-selective assessment of agricultural workers' personal exposure to airborne fungi and fungal fragments. Sci. Total Environ. 2014, 466-467, 725-732. [CrossRef]

60. Damialis, A.; Konstantinou, G.N. Cereal pollen sensitisation in pollen allergic patients: To treat or not to treat? Eur. Ann. Allergy Clin. Immunol. 2011, 43, 36-44.

61. Ercilla-Montserrat, M.; Izquierdo, R.; Belmonte, J.; Montero, J.I.; Muñoz, P.; de Linares, C.; Rieradevall, J. Building-integrated agriculture: A first assessment of aerobiological air quality in rooftop greenhouses (i-RTGs). Sci. Total Environ. 2017, 598, 109-120. [CrossRef]

62. Adhikari, A.; Sen, M.M.; Gupta-Bhattacharya, S.; Chanda, S. Studies on airborne fungal spores from two indoor cowsheds of suburban and rural areas of West Bengal, India. Indoor Built Environ. 1999, 8, 221-229. [CrossRef]

63. Campbell, A.R.; Swanson, M.C.; Fernandez-Caldas, E.; Reed, C.E.; May, J.J.; Pratt, D.S. Aeroallergens in Dairy Barns near Cooperstown, New York and Rochester, Minnesota. Am. Rev. Respir. Dis. 1989, 140, 317-320. [CrossRef]

64. Letourneau, V.; Meriaux, A.; Goyer, N.; Chakir, J.; Cormier, Y.; Duchaine, C. Biological activities of respirable dust from eastern canadian peat moss factories. Toxicol. Vitro 2010, 24, 1273-1278. [CrossRef]

65. Swan, J.R.M.; Kelsey, A.; Crook, B.; Gilbert, E.J. Occupational and Environmental Exposure to Bioaerosols from Composts and Potential Health Effects-A Critical Review of Published Data; Health and Safety Executive (HSE) Books: Sudbury, UK, 2003.

66. Raulf, M.; Buters, J.; Chapman, M.; Cecchi, L.; de Blay, F.; Doekes, G.; Eduard, W.; Heederik, D.; Jeebhay, M.F.; Kespohl, S.; et al. Monitoring of occupational and environmental aeroallergens-EAACI position paper concerted action of the EAACI IG occupational allergy and aerobiology \& air Pollution. Allergy 2014, 69, 1280-1299. [CrossRef]

67. Taytard, A.; Tessier, J.F.; Faugere, J.G.; Vergeret, J.; Freour, P. Respiratory function and bronchial reactivity in mill workers. Eur. J. Epidemiol. 1988, 4, 326-330. [CrossRef]

68. Just, N.; Duchaine, C.; Singh, B. An aerobiological perspective of dust in cage-housed and floor-housed poultry operations. J. Occup. Med. Toxicol. 2009, 4, 13. [CrossRef]

69. Rodolfi, M.; Lorenzi, E.; Picco, A.M. Study of the occurrence of greenhouse microfungi in a botanical garden. J. Phytopathol. 2003, 151, 591-599. [CrossRef]

70. Wierzbicka, A.; Pedersen, E.; Persson, R.; Nordquist, B.; Stålne, K.; Gao, C.; Harderup, L.E.; Borell, J.; Caltenco, H.; Ness, B.; et al. Healthy indoor environments: The need for a holistic approach. Int. J. Environ. Res. Public Health 2018, 15, 1874. [CrossRef]

71. Radulescu, H.C.; Rosu, G.; Popescu, C.; Ispas, A.; Ghituleasa, P.C.; Lazar, V. A microbial survey of the museal airborne fungal biodeteriogens. Ge-Conservation 2017, 11, 86-94. 
72. Sommerstein, R.; Fux, C.A.; Vuichard-Gysin, D.; Abbas, M.; Marschall, J.; Balmelli, C.; Troillet, N.; Harbarth, S.; Schlegel, M.; Widmer, A.; et al. Risk of SARS-CoV-2 transmission by aerosols, the rational use of masks, and protection of healthcare workers from COVID-19. Antimicrob. Resist. Infect. Control. 2020, 9, 100. [CrossRef]

73. Chen, C. Citespace II: Detecting and visualizing emerging trends and transient patterns in scientific literature. J. Am. Soc. Inf. Sci. Technol. 2006, 57, 359-377. [CrossRef]

74. Chen, C. Searching for intellectual turning points: Progressive knowledge domain visualization. Proc. Natl. Acad. Sci. USA. 2004, 101, 5303-5310. [CrossRef]

75. Chen, C. The structure and dynamics of scientific knowledge. In Mapping Scientific Frontiers; Springer: London, UK, 2013; pp. 163-199. [CrossRef]

76. Kleinberg, J. Bursty and hierarchical structure in streams. Data Min. Knowl. Discov. 2002, 7, 373-397. [CrossRef]

77. R.H.O. Aerobiology studies pests that come with the wind. J. Frankl. Inst. 1938, 226, 571-572. [CrossRef]

78. Chen, C. The CiteSpace Manual 2014. Available online: https://www.researchgate.net/profile/Arsev_Aydinoglu/publication/27 4377526_Collaborative_interdisciplinary_astrobiology_research_a_bibliometric_study_of_the_NASA_Astrobiology_Institute/ links/5670463b08ae0d8b0cc0e112.pdf (accessed on 5 February 2021).

79. Sun, Y.; Wu, S.; Gong, G. Trends of research on polycyclic aromatic hydrocarbons in food: A 20-year perspective from $1997-2017$. Trends Food Sci. Technol. 2019, 83, 86-98. [CrossRef]

80. Xiao, F.; Li, C.; Sun, J.; Zhang, L. Knowledge domain and emerging trends in organic photovoltaic technology: A scientometric review based on CiteSpace analysis. Front. Chem. 2017, 5, 67. [CrossRef] [PubMed]

81. Intergovernmental Panel on Climate Change (IPCC). Climate Change 2014: Synthesis Report; IPCC: Geneva, Switzerland, 2014; Available online: https:/ / www.ipcc.ch/report/ar5/syr/ (accessed on 29 November 2020).

82. Intergovernmental Panel on Climate Change (IPCC). Summary for policymakers. In Global Warming of $1.5^{\circ} \mathrm{C}$. An IPCC Special Report on the Impacts of Global wWarming of $1.5^{\circ} \mathrm{C}$ Above Pre-Industrial Levels and Related Global Greenhouse Gas Emission Pathways in the Context of Strengthening the Global Response to the Threat of Climate Change, Sustainable Development, and Efforts to Eradicate Poverty; World Meteorological Organization: Geneva, Switzerland, 2018; Available online: https://www.ipcc.ch/site/assets/ uploads/sites/2/2019/05/SR15_SPM_version_report_LR.pdf (accessed on 29 November 2020).

83. Chiabai, A.; Quiroga, S.; Martinez-Juarez, P.; Higgins, S.; Taylor, T. The nexus between climate change, ecosystem services and human health: Towards a conceptual framework. Sci. Total Environ. 2018, 635, 1191-1204. [CrossRef] [PubMed]

84. McGushin, A.; Tcholakov, Y.; Hajat, S. Climate change and human health: Health impacts of warming of $1.5^{\circ} \mathrm{C}$ and $2{ }^{\circ} \mathrm{C}$. Int. J. Environ. Res. Public Health 2018, 15, 1123. [CrossRef] [PubMed]

85. Patz, J.A.; Thomson, M.C. Climate change and health: Moving from theory to practice. PLoS Med. 2018, 15, e1002628. [CrossRef]

86. Schulte, P.A.; Bhattacharya, A.; Butler, C.R.; Chun, H.K.; Jacklitsch, B.; Jacobs, T.; Kiefer, M.; Lincoln, J.; Pendergrass, S.; Shire, J.; et al. Advancing the framework for considering the effects of climate change on worker safety and health. J. Occup. Environ. Hyg. 2016, 13, 847-865. [CrossRef]

87. Applebaum, K.M.; Graham, J.; Gray, G.M.; la Puma, P.; McCormick, S.A.; Northcross, A.; Perry, M.J. An overview of occupational risks from climate change. Curr. Environ. Health Rep. 2016, 3, 13-22. [CrossRef]

88. Marchetti, E.; Capone, P.; Freda, D. Climate change impact on microclimate of work environment related to occupational health and productivity. Ann. Ist. Super. Sanità 2016, 52, 338-342. [CrossRef]

89. Levi, M.; Kjellstrom, T.; Baldasseroni, A. Impact of climate change on occupational health and productivity: A systematic literature review focusing on workplace heat. Med. Lav. 2018, 109, 163-179. [CrossRef]

90. Bonafede, M.; Marinaccio, A.; Asta, F.; Schifano, P.; Michelozzi, P.; Vecchi, S. The association between extreme weather conditions and work-related injuries and diseases. A systematic review of epidemiological studies. Ann. Ist. Super. Sanità 2016, 52, 357-367. [CrossRef]

91. D'Ovidio, M.C.; Grandi, C.; Marchetti, E.; Polichetti, A.; Iavicoli, S. Preface. Climate change and occupational health. Ann. Ist. Super. Sanità 2016, 52, 323-324. [CrossRef]

92. Grandi, C.; D'Ovidio, M.C. Balance between health risks and benefits for outdoor workers exposed to solar radiation: An overview on the role of near infrared radiation alone and in combination with other solar spectral bands. Int. J. Environ. Res. Public Health 2020, 17, 1357. [CrossRef]

93. Vonesch, N.; D’Ovidio, M.C.; Melis, P.; Remoli, M.E.; Ciufolini, M.G.; Tomao, P. Climate change, vector-borne diseases and working population. Ann. Ist. Super. Sanità 2016, 52, 397-405. [CrossRef]

94. D'Ovidio, M.C.; Annesi-Maesano, I.; D'Amato, G.; Cecchi, L. Climate change and occupational allergies: An overview on biological pollution, exposure and prevention. Ann. Ist. Super. Sanità 2016, 52, 406-414. [CrossRef]

95. Wild, C.P. Complementing the genome with an "exposome": The outstanding challenge of environmental exposure measurement in molecular epidemiology. Cancer Epidemiol. Biomark. Prev. 2005, 14, 1847-1850. [CrossRef]

96. Siroux, V.; Agier, L.; Slama, R. The exposome concept: A challenge and a potential driver for environmental health research. Eur. Respir. Rev. 2016, 25, 124-129. [CrossRef]

97. Holland, N. Future of environmental research in the age of epigenomics and exposomics. Rev. Environ. Health 2017, 32, 45-54. [CrossRef]

98. Vineis, P.; Robinson, O.; Chadeau-Hyam, M.; Dehghan, A.; Mudway, I.; Dagnino, S. What is new in the exposome? Environ. Int. 2020, 143, 105887. [CrossRef] 
99. Subramanian, I.; Verma, S.; Kumar, S.; Jere, A.; Anamika, K. Multi-omics data integration, interpretation, and its application. Bioinform. Biol. Insights 2020, 14, 1-24. [CrossRef] [PubMed]

100. Jung, G.T.; Kim, K.-P.; Kim, K. How to interpret and integrate multi-omics data at systems level. Anim. Cells Syst. 2020, 24, 1-7. [CrossRef] [PubMed]

101. Chen, W.; Li, S.; Kulkarni, A.S.; Huang, L.; Cao, J.; Qian, K.; Wan, J. Single Cell Omics: From Assay Design to Biomedical Application. Biotechnol. J. 2020, 15, 1900262. [CrossRef] [PubMed]

102. García-Sánchez, J.; Trigo, M.D.M.; Recio, M. Extraction and quantification of Ole e 1 from atmospheric air samples: An optimized protocol. Chemosphere 2019, 225, 490-496. [CrossRef]

103. Banchi, E.; Ametrano, C.G.; Tordoni, E.; Stanković, D.; Ongaro, S.; Tretiach, M.; Pallavicini, A.; Muggia, L.; ARPA Working Group. Environmental DNA assessment of airborne plant and fungal seasonal diversity. Sci. Total Environ. 2020, 738, 140249. [CrossRef]

104. Rojo, J.; Nunez, A.; Lara, B.; Sanchez-Parra, B.; Moreno, D.A.; Perez-Badia, R. Comprehensive analysis of different adhesives in aerobiological sampling using optical microscopy and high-throughput DNA sequencing. J. Environ. Manag. 2019, 240, 441-450. [CrossRef]

105. Fernandez, M.O.; Thomas, R.J.; Garton, N.J.; Hudson, A.; Haddrell, A.; Reid, J.P. Assessing the airborne survival of bacteria in populations of aerosol droplets with a novel technology. J. R. Soc. Interface 2019, 16, 20180779. [CrossRef]

106. Emmerson, K.M.; Silver, J.D.; Newbigin, E.; Lampugnani, E.R.; Suphioglu, C.; Wain, A.; Ebert, E. Development and evaluation of pollen source methodologies for the Victorian Grass Pollen Emissions Module VGPEM1.0. Geosci. Model. Dev. 2019, 12, 2195-2214. [CrossRef]

107. Ruga, L.; Orlandi, F.; Fornaciari, M. Preventive conservation of cultural heritage: Biodeteriogens control by aerobiological monitoring. Sensors 2019, 19, 3647. [CrossRef]

108. Dommergue, A.; Amato, P.; Tignat-Perrier, R.; Magand, O.; Thollot, A.; Joly, M.; Bouvier, L.; Sellegri, K.; Vogel, T.; Sonke, J.E.; et al. Methods to investigate the global atmospheric microbiome. Front. Microbiol. 2019, 10, 243. [CrossRef]

109. De Weger, L.A.; Molster, F.; de Raat, K.; den Haan, J.; J Romein, J.; van Leeuwen, W.; de Groot d, H.; Mostert, M.; Hiemstra, P.S. A new portable sampler to monitor pollen at street level in the environment of patients. Sci. Total Environ. 2020, 741, 140404. [CrossRef]

110. Oteros, J.; Weber, A.; Kutzora, S.; Rojo, J.; Heinze, S.; Herr, C.; Gebauer, R.; Schmidt-Weber, C.B.; Buters, J.T.M. An operational robotic pollen monitoring network based on automatic image recognition. Environ. Res. 2020, 191, 110031. [CrossRef]

111. Fiorina, A.; Scordamaglia, A.; Fumagalli, F.; Canonica, G.W.; Passalacqua, G. Aerobiological diagnosis of respiratory allergy by a personal sampler: Two case reports. J. Investig. Allergol. Clin. Immunol. 2003, 13, 284-285.

112. Fiorina, A.; Scordamaglia, A.; Mincarini, M.; Fregonese, L.; Canonica, G.W. Aerobiologic particle sampling by a new personal collector (Partrap FA52) in comparison to the Hirst (Burkard) sampler. Allergy 1997, 52, 1026-1030. [CrossRef]

113. Kron, P.; Loureiro, J.; Castro, S.; Čertner, M. Flow cytometric analysis of pollen and spores: An overview of applications and methodology. Cytometry A. 2021. [CrossRef]

114. Dunker, S.; Motivans, E.; Rakosy, D.; Boho, D.; Mäder, P.; Hornick, T.; Knight, T.M. Pollen analysis using multispectral imaging flow cytometry and deep learning. New Phytol. 2021, 229, 593-606. [CrossRef]

115. D'Ovidio, M.C.; di Renzi, S.; Capone, P.; Pelliccioni, A. Pollen and fungal spores evaluation in relation to occupants and microclimate in indoor workplaces. Sustainability 2021, 13, 3154. [CrossRef]

116. Damialis, A.; Gilles, S.; Sofiev, M.; Sofieva, V.; Kolek, F.; Bayr, D.; Plaza, M.P.; Leier-Wirtz, V.; Kaschuba, S.; Ziska, L.H.; et al. Higher airborne pollen concentrations correlated with increased SARS-CoV-2 infection rates, as evidenced from 31 countries across the globe. Proc. Natl. Acad. Sci. USA 2021, 18, e2019034118. [CrossRef]

117. Lam, H.C.Y.; Jarvis, D.; Fuertes, E. Interactive effects of allergens and air pollution on respiratory health: A systematic review. Sci. Total Environ. 2021, 757, 143924. [CrossRef]

118. Zhou, S.; Wang, X.; Lu, S.; Yao, C.; Zhang, L.; Rao, L.; Liu, X.; Zhang, W.; Li, S.; Wang, W.; et al. Characterization of allergenicity of Platanus pollen allergen a 3 (Pla a 3) after exposure to $\mathrm{NO}_{2}$ and $\mathrm{O}_{3}$. Environ. Pollut. 2021, 278, 116913. [CrossRef]

119. Cariñanos, P.; Foyo-Moreno, I.; Alados, I.; Guerrero-Rascado, J.L.; Ruiz-Peñuela, S.; Titos, G.; Cazorla, A.; Alados-Arboledas, L.; Díaz de la Guardia, C. Bioaerosols in urban environments: Trends and interactions with pollutants and meteorological variables based on quasi-climatological series. J. Environ. Manag. 2021, 282, 111963. [CrossRef]

120. Anenberg, S.C.; Haines, S.; Wang, E.; Nassikas, N.; Kinney, P.L. Synergistic health effects of air pollution, temperature, and pollen exposure: A systematic review of epidemiological evidence. Environ. Health 2020, 19, 130. [CrossRef]

121. Ortega-Rosas, C.I.; Meza-Figueroa, D.; Vidal-Solano, J.R.; González-Grijalva, B.; Schiavo, B. Association of airborne particulate matter with pollen, fungal spores, and allergic symptoms in an arid urbanized area. Environ. Geochem. Health 2020. [CrossRef]

122. Hugg, T.T.; Hjort, J.; Antikainen, H.; Rusanen, J.; Tuokila, M.; Korkonen, S.; Weckström, J.; Jaakkola, M.S.; Jaakkola, J.J.K. Urbanity as a determinant of exposure to grass pollen in Helsinki Metropolitan area, Finland. PLoS ONE 2017, 12, e0186348. [CrossRef]

123. Idrose, N.S.; Walters, E.H.; Zhang, J.; Vicendese, D.; Newbigin, E.J.; Douglass, J.A.; Erbas, B.; Lowe, A.J.; Perret, J.L.; Lodge, C.J.; et al. Outdoor pollen-related changes in lung function and markers of airway inflammation: A systematic review and meta-analysis. Clin. Exp. Allergy 2021. [CrossRef]

124. Hoogeveen, M.J.; van Gorp, E.C.M.; Hoogeveen, E.K. Can pollen explain the seasonality of flu-like illnesses in the Netherlands? Sci. Total Environ. 2021, 755, 143182. [CrossRef] 
125. Hoogeveen, M.J. Pollen likely seasonal factor in inhibiting flu-like epidemics. A Dutch study into the inverse relation between pollen counts, hay fever and flu-like incidence 2016-2019. Sci. Total Environ. 2020, 727, 138543. [CrossRef]

126. Awaya, A.; Kuroiwa, Y. The relationship between annual airborne pollen levels and occurrence of all cancers, and lung, stomach, colorectal, pancreatic and breast cancers: A retrospective study from the National Registry Database of cancer incidence in Japan, 1975-2015. Int. J. Environ. Res. Public Health 2020, 17, 3950. [CrossRef]

127. McInnes, R.N.; Hemming, D.; Burgess, P.; Lyndsay, D.; Osborne, N.J.; Skjøth, C.A.; Thomas, S.; Vardoulakis, S. Mapping allergenic pollen vegetation in UK to study environmental exposure and human health. Sci. Total Environ. 2017, 599, 483-499. [CrossRef]

128. Maya-Manzano, J.M.; Sadyś, M.; Tormo-Molina, R.; Fernández-Rodríguez, S.; Oteros, J.; Silva-Palacios, I.; Gonzalo-Garijo, A. Relationships between airborne pollen grains, wind direction and land cover using GIS and circular statistics. Sci. Total Environ. 2017, 584, 603-613. [CrossRef]

129. Devadas, R.; Huete, A.R.; Vicendese, D.; Erbas, B.; Beggs, P.J.; Medek, D.; Haberle, S.G.; Newnham, R.M.; Johnston, F.H.; Jaggard, A.K.; et al. Dynamic ecological observations from satellites inform aerobiology of allergenic grass pollen. Sci. Total Environ. 2018, 633, 441-451. [CrossRef] [PubMed]

130. Gernes, R.; Brokamp, C.; Rice, G.E.; Wright, J.M.; Kondo, M.C.; Michael, Y.L.; Kondo, M.C.; Michael, Y.L.; Donovan, G.H.; Gatziolis, D.; et al. Using high-resolution residential greenspace measures in an urban environment to assess risks of allergy outcomes in children. Sci. Total Environ. 2019, 668, 760-767. [CrossRef] [PubMed]

131. Zhou, Y.; Bui, D.S.; Perret, J.L.; Lowe, A.J.; Lodge, C.J.; Markevych, I.; Heinrich, J.; Bloom, M.S.; Knibbs, L.D.; Jalaludin, B.; et al. Greenness may improve lung health in low-moderate but not high air pollution areas: Even Northeastern Cities' study. Thorax 2021. [CrossRef] [PubMed]

132. Stas, M.; Aerts, R.; Hendrickx, M.; Delcloo, A.; Dendoncker, N.; Dujardin, S.; Linard, C.; Nawrot, T.; van Nieuwenhuyse, A.; Aerts, J.-M.; et al. Exposure to green space and pollen allergy symptom severity: A case-crossover study in Belgium. Sci. Total Environ. 2021, 781, 146682. [CrossRef] [PubMed] 